\title{
Sterilization procedures and Plant Preservative Mixture on in vitro establishment of Miscanthus sinensis Andersson
}

\author{
Ana da Silva Ledo ${ }^{1 *}$, Adriane Leite do Amaral ${ }^{1}$, Maria M. Jenderek², Melanie Harrison ${ }^{3}$, Daniel K. Manter ${ }^{4}$
}

\section{ABSTRACT}

Information about the establishment phase of Miscanthus sinensis Andersson as sterile procedure to avoid the contamination were few reported. The aim of this study was to evaluate different immersion sterilization procedures with and without the biocide, Plant Preservative Mixture ( $\left.\mathrm{PPM}^{\mathrm{TM}}\right)$ on in vitro contamination of two Miscanthus genotypes. The plant material were canes from adult plants of two accessions PI 668371 and PI 668375 cultivated in the germplasm bank of USDA-ARS, Griffin, Georgia. Apical meristems were submitted to immersion sterilization procedures (70\% isopropyl alcohol and $1.5,5.0$ or $8.25 \% \mathrm{NaOCl}$ for different time periods, followed by rinsing three times with autoclaved distilled water. After that, the explants were inoculated on MS basal medium in the presence or absence of $1 \mathrm{~mL} \mathrm{~L}^{-1} \mathrm{PPM}^{\mathrm{TM}}$. The experimental design was fully randomized in a $2 \times 5 \times 2$ factorial scheme (genotypes $\mathrm{x}$ sterilization process $\times \mathrm{PPM}^{\top M}$ ) with five replicates per treatment and five apical meristems per experimental unit. Aseptic treatments showed no differences for percentage of bacterial and fungal contaminations and percentage of explant survival. In the presence of PPM ${ }^{\mathrm{TM}}$ there was less bacterial contamination in the accessions $(28 \%)$ than in the absence $(100 \%)$. For the percentage of fungal contamination, PPM ${ }^{\mathrm{TM}}$ had no significant effect on PI 668371 accession. However, on PI 668375 accession there was a lower percentage of fungal contamination (16\%). The biocide PPM ${ }^{\mathrm{TM}}$ may be an efficient agent to prevent bacterial contamination on in vitro cultures of Miscanthus spp and fungal contamination in PI 668375 accession.

Index terms: Micropropagation; in vitro contamination; Saccharum complex.

\section{INTRODUCTION}

Miscanthus genus belongs to Andropogoneae tribe of Poaceae (Gramineae/grass) family and in its natural habit forms dense canes brakes and has some economic potential as an ornamental, forage, grazing, housebuilding and archery (Daniels; Roach, 1987). This genus also has been investigated in terms of yield potential for cellulose fiber production and present an alternative source of bioenergy (Carroll; Somerville, 2009; Jakob; Zhou; Paterson, 2009; Stewart et al., 2009; Clifton-Brown et al., 2017).

Genetic variability in breeding sugarcane program of the Brazilian Agricultural Research Corporation (EMBRAPA) is priority, and diversity of Saccharum complex genotypes and other genus as Miscanthus had been recently intensified by introduction from the US of several accessions by stem and in vitro plants. The National Repository of Miscanthus is located at the Plant Genetic Resources Conservation Unit, Griffin, GA and Subtropical Horticulture Research Station, Miami, Florida. However, the first Brazilian introduction of 10 genotypes presented high levels of contamination affecting in vitro establishment.

Miscanthus sinensis presented high genetic diversity and biomass yield and due to its fertility can be used as a breeding material (Christian; Yates; Riche, 2005; Stewart et al., 2009). However, Miscanthus hybrids, due to their lack of fertility, must be propagated asexually by rhizome fragments (Christian; Yates; Riche, 2005) or nodal stem cuttings (Atkinson, 2009; Boersma; Heaton, 2012). According Christian, Yates and Riche (2005) and Atkinson (2009), a main constraint to explore as a bioenergy crop is high cost of field establishing from rhizomes or plantlets.

Some works were published concerned to development for in vitro regeneration of Miscanthus. Wang et al. (2011) were the first authors to report on the establishment of the in vitro culture of Miscanthus sinensis using mature seeds and observed variation of callus formation among accessions. However, information about the establishment phase as sterile procedure to avoid the contamination in Miscanthus species are few compared with Saccharum species (Khan et al., 2007; Tiwari; Arya; Kumar, 2012; Mekonnen; Diro;

Received in October, 2019 and approved in April, 2020

${ }^{1}$ Empresa Brasileira de Pesquisa Agropecuária/Embrapa Tabuleiros Costeiros, Aracaju, SE, Brasil

${ }^{2}$ U.S. Department of agriculture/USDA, Agricultural Research Service/ARS, National Center for Genetic Resources Preservation, Fort Collins, USA

${ }^{3}$ U.S. Department of Agriculture/USDA, Agricultural Research Service/ARS, Plant Genetic Resources Conservation Unit, Griffin, USA

${ }^{4}$ U.S. Department of Agriculture/USDA, Agricultural Research Service/ARS, Soil Management and Sugarbeet Research, Fort Collins, USA

${ }^{*}$ Corresponding author: ana.ledo@embrapa.br 
Sharma, 2013). Little literature has been published about occurrence of bacterial communities in Miscanthus sp. (Copy-Selby et al., 2017). The studies are concentrated for Saccharum species as reported by Magnani et al. (2010).

Plant Preservative Mixture (PPM ${ }^{\mathrm{TM}}$ ) is a proprietary combination of two broad-spectrum industrial isothiazolone biocides, methylisothiazolone (MI) and chloromethylisothiazolone (CMI) (Rihan et al., 2012). PPM was introduced in plant tissue culture application in 1996 and has been proven to be effective for decontaminating surface microflora of explant tissues (Niedz, 1998). It affects key enzymes in the Krebs cycle and in the Electron Transport Chain. The ability of PPM ${ }^{\mathrm{TM}}$ to prevent microbial contaminants at culture initiation has been reported for some species as sugarcane (Digonzelli; Díaz; Carrizo de Bellone, 2005), Brassica oleracea (Rihan et al., 2012), Petunia hybrida (Miyazaki; Tan; Errington, 2010), Calophyllum brasiliense (Silveira et al., 2016), Nasturtium officinale (Faizy; Al-Zubaydi; Nair, 2017) among others.

Tissue culture techniques can be improved as vegetative clonal plant propagation to promote uniform crops of superior germplasm and in vitro propagation has been an important step to preserve healthy and genetic integrity of collections, by multiplication of accessions before and recovery them after slow growth or cryopreservation. Therefore, the aim of this study was to evaluate different aseptic procedures and the effects of $\mathrm{PPM}^{\mathrm{TM}}$ on in vitro contamination of two Miscanthus genotypes.

\section{MATERIAL AND METHODS}

\section{Plant material and shoot cultures}

Canes from Miscanthus sinensis Andersson adult plants cultivated in the field, were provided by the Plant Genetic Resources Conservation Unit (USDA-ARS), Griffin, Georgia. Two accessions, PI 668371 and PI 668375, were used in this experiment. Canes, 8-12 inches of length, were packaged with Sphagnum moss and sent to National Center for Genetic Resources Preservation (USDA-ARS), Fort Collins, CO. After inventory, canes were washed in running tap water and stored in humid towels until disinfestation.

\section{Sterilization procedures}

The processing was divided in two phases. First phase: canes with identification of the top-most node by peeling the top leaves from the cane, cutting cane below the node and just below the spread leaves at top of the cane, 4-6 inches of length; second phase: in flow chamber, explants were immersed in solution of $70 \%$ isopropyl alcohol and $1.5,5.0$ or $8.25 \%$ sodium hypochlorite solution $(\mathrm{NaOCl})$ for different time periods (Table 1), rinsed three times, 10 minutes each. Each wash was performed in separated sterile beakers with autoclaved distilled water to remove traces of hypochlorite solution. During the sterilization process, the solutions and explants were maintained in sterile beakers on rotary shaker at $100 \mathrm{rpm}$.

Table 1 - Sterilization procedures applied in cane top, 4-6 inches of length, of Miscanthus sinensis genotypes before apical meristem is excised.

\begin{tabular}{ccc}
\hline $\begin{array}{c}\text { Sterilization } \\
\text { procedure }\end{array}$ & Isopropyl alcohol & $\mathrm{NaOCl}$ \\
\hline 1 & $10 \mathrm{~min} 70 \%$ isopropyl & $20 \min 1.5 \% \mathrm{NaOCl}$ \\
2 & $15 \mathrm{~min} 70 \%$ isopropyl & $10 \min 5.0 \% \mathrm{NaOCl}$ \\
3 & $15 \mathrm{~min} 70 \%$ isopropyl & $20 \min 5.0 \% \mathrm{NaOCl}$ \\
4 & $15 \mathrm{~min} 70 \%$ isopropyl & $10 \min 8.25 \% \mathrm{NaOCl}$ \\
5 & $15 \min 70 \%$ isopropyl & $20 \min 8.25 \% \mathrm{NaOCl}$ \\
\hline
\end{tabular}

Leaf sheaths damaged during sterilization process were removed and the apical meristems excised with sterilized scalpels, maintained in Petri dishes and inoculated in Magenta"' box ( $\mathrm{h} \times \mathrm{I} \times \mathrm{w}$ : $77 \mathrm{~mm} \times 77 \mathrm{~mm} \times$ $97 \mathrm{~mm}$ ), one per box, with $60 \mathrm{~mL}$ MS basal medium in the presence or absence of $1 \mathrm{~mL} \mathrm{~L}^{-1} \mathrm{PPM}^{\mathrm{TM}}$ (Plant Cell Technology, Inc.), supplemented with $0.1 \mathrm{mg} \mathrm{L}^{-1}$ 6-Benzylaminopurine (BAP) + $0.2 \mathrm{mg} \mathrm{L}^{-1}$ Indole-3butyric acid (IBA) + $0.1 \mathrm{mg} \mathrm{L}^{-1}$ 6-Furfurylaminopurine (Kinetin) + $0.1 \mathrm{mg} \mathrm{L}^{-1} 1$-naphthylacetic acid (NAA), 2\% sucrose and $0.7 \%$ agar. Cultures were transferred to growth chamber with the following environmental conditions: temperature of $25 \pm 2{ }^{\circ} \mathrm{C}, 16 \mathrm{~h}$ light photoperiod, relative humidity of $70-80 \%$, and indirect fluorescent light intensity of $75 \mu \mathrm{mol} \mathrm{m} \mathrm{m}^{-2} \mathrm{~s}^{-1}$. Data were recorded on percentage of contaminated cultures by 
bacterial and fungal and explant survival percentage per treatment combinations after 30 days of inoculation and transformed by arcsine $\mathrm{v}$. For a preliminary study of bacterial groups associated with Miscanthus in vitro culture, each bacterial contaminant was subcultured in $3 \mathrm{~mL}$ LB Broth (10855-001, Gibco ${ }^{\circ}$ ) medium.

In order to identify the strains, extraction of genomic DNA, amplification and analysis of 16S rRNA genes were conducted as follows: Genomic DNA was extracted from the isolated bacteria strains using the Genomic DNA Prep kit and then used as a template for PCR to amplify the $16 \mathrm{~S}$ rRNA gene. A universal bacterial primer set of 27F (5'-AGA GTT TGA TCC TGG CTC AG$\left.3^{\prime}\right)$, Lane (1991) and 1492R (5'-GGT TAC CTT GTT ACG $A C T$ T-3') was used to amplify the nearly complete $16 S$ rRNA gene. The PCR product was then purified using a SolGent PCR purification kit according to the manufacturer's instructions. The amplified $16 \mathrm{~S}$ rRNA gene was sequenced using an $A B I$ BigDye Terminator v3.1 cycle sequencing kit (Applied Biosystems, Foster City, Cal., USA) and an ABI 3730XL DNA analyzer (Applied Biosystems, Foster City, Cal., USA).

\section{Experimental design and statistical evaluation}

Experimental design was fully randomized in a $2 \times 5 \times 2$ factorial scheme (2 genotypes $\times 5$ sterilization procedures $\times 2 \mathrm{PPM}^{\mathrm{TM}}$ concentrations) with five replicates per treatment and five apical meristems per experimental unit. Data were converted into percentages and means were compared by Tukey test at $5 \%$ probability. For statistical analysis, the SAS - Statistical Analysis System program (SAS version 9.2) was used.

\section{RESULTS AND DISCUSSION}

Analysis of variance (ANOVA) revealed that the use of $\mathrm{PPM}^{\mathrm{TM}}$ for bacterial contamination and explant survival percentages and interaction between genotypes and $\mathrm{PPM}^{\mathrm{TM}}$ for fungal contamination were significant after 30 days of culture. Sterile treatments, genotypes and some interactions presented non-significant effect on the establishment of aseptic culture (Table 2).

The highest level of bacterial contamination (100\%) and lowest explant survival (0\%) were recorded in medium without PPM ${ }^{\mathrm{TM}}$ (Table 3). This might be due to the fact that
$\mathrm{PPM}^{\mathrm{TM}}$ is a combination of two broad-spectrum industrial isothiazolone biocides, chloromethylisothiazolone and methylisothiazolone (Rihan et al., 2012). In the presence of $1 \mathrm{~mL} \mathrm{~L}^{-1} \mathrm{PPM}^{\mathrm{TM}}$, data showed $28.00 \%$ of bacterial contamination and $64.00 \%$ of survival. Saccharum spp. apical meristem in vitro cultures presented inhibition of Pseudomonas growth in medium with $0.25,0.50$ and $0.75 \mathrm{~mL} \mathrm{~L}^{-1}$ PPM $^{\text {тM }}$ (Digonzelli; Díaz; Carrizo de Bellone, 2005). Bacterial contamination observed in the presence of $\mathrm{PPM}^{\mathrm{TM}}(28 \%)$, probably is due to endophytic bacteria and the eradication of this type of bacteria is problematic since target microbial cells are not directly exposed to the biocide (Miyazaki; Tan; Errington, 2010). Thomas, Agrawal and Bharathkumar (2017) reported the prevalence of diverse $\mathrm{PPM}^{\mathrm{TM}}$-tolerant endophytic bacteria in Papaya carica $\mathrm{L}$.

Table 2 - Analysis of variance of bacterial and fungal contaminations and explant survival in relation to the effect of Miscanthus sinensis genotypes (Gen), sterilization procedures (Ster) and PPM ${ }^{\mathrm{TM}}$.

\begin{tabular}{|c|c|c|c|c|}
\hline \multirow[t]{2}{*}{ Variation factor } & \multirow[t]{2}{*}{ DF } & \multicolumn{3}{|c|}{ Mean Square } \\
\hline & & Bacterial (\%) & Fungal (\%) & Survival \\
\hline Genotype & 1 & $0.77 n s$ & $2.13 \mathrm{~ns}$ & $0.71 \mathrm{~ns}$ \\
\hline $\begin{array}{c}\text { Sterilization } \\
\text { treatment (Ster) }\end{array}$ & 4 & $0.0235 \mathrm{~ns}$ & $0.32 \mathrm{~ns}$ & $0.09 \mathrm{~ns}$ \\
\hline $\mathrm{PPM}^{\mathrm{TM}}$ & 1 & $33.47 * * *$ & $3.12 \mathrm{~ns}$ & $26.44 * * *$ \\
\hline Gen * Ster & 4 & $0.27 \mathrm{~ns}$ & $0.09 \mathrm{~ns}$ & $0.26 \mathrm{~ns}$ \\
\hline Gen $* \mathrm{PPM}^{\mathrm{TM}}$ & 1 & $0.02 \mathrm{~ns}$ & $2.434^{*}$ & $0.07 \mathrm{~ns}$ \\
\hline Ster * PPM $^{\mathrm{TM}}$ & 4 & 0.03 ns & $0.64 \mathrm{~ns}$ & $0.10 \mathrm{~ns}$ \\
\hline Gen * Ster * PPM ${ }^{\mathrm{TM}}$ & 4 & $0.29 \mathrm{~ns}$ & $0.86 \mathrm{~ns}$ & $0.28 \mathrm{~ns}$ \\
\hline Error & 85 & 0.26 & 0.458 & 0.29 \\
\hline VC (\%) & & & 145.26 & 112.55 \\
\hline
\end{tabular}

Data transformed by arcsine $\mathrm{x} ; * * *$, very highly significant $(\mathrm{p} \leq$ $0.0001) ; *$, significant $(p \leq 0.05)$ and $n s$, non-significant $(p>0.05)$ by the Tukey test at $5 \%$ probability of error.

For fungal contamination, $\mathrm{PPM}^{\mathrm{TM}}$ had nonsignificant effect on the PI 668371. However, for PI 668375 the absence of PPM contributes for high fungal contamination (56.67\%) as compared with its presence (16.00\%). Considering the data showed, contamination level on PI 668375 was higher than PI 668371 in absence the of $\operatorname{PPM}^{\mathrm{TM}}(p<0.05)$. 
Table 3 - Effect of presence and absence of $\mathrm{PPM}^{\mathrm{TM}}$ on in vitro Miscanthus sinensis genotypes for percentage of bacterial and fungal contaminations and explant survival percentage.

\begin{tabular}{cccc}
\hline $\mathrm{PPM}^{\mathrm{TM}}\left(\mathrm{mL} \mathrm{L}^{-1}\right)$ & \multicolumn{2}{c}{ Genotypes } & Means \\
\cline { 2 - 3 } & Pl 668371 & Pl 668375 \\
\hline \multicolumn{4}{c}{ Bacterial contamination (\%) } \\
\hline 0.0 & $100.00 \mathrm{Aa}$ & $100.00 \mathrm{Aa}$ & $100.00 \mathrm{~A}$ \\
1.0 & $20.00 \mathrm{Aa}$ & $36.00 \mathrm{Aa}$ & $28.00 \mathrm{~B}$ \\
\hline Means & $60.00 \mathrm{a}$ & $68.00 \mathrm{a}$ \\
\hline \multicolumn{4}{c}{ Fungal contamination (\%) } \\
\hline 0.0 & $20.00 \mathrm{Ab}$ & $56.67 \mathrm{Aa}$ & $38.34 \mathrm{~A}$ \\
1.0 & $20.00 \mathrm{Ab}$ & $16.00 \mathrm{Bb}$ & $18.00 \mathrm{~A}$ \\
\hline Means & $20.00 \mathrm{a}$ & $38.18 \mathrm{a}$ \\
\hline \multicolumn{4}{c}{ Explant survival (\%) } \\
\hline 0.0 & $0.00 \mathrm{Aa}$ & $0.00 \mathrm{Aa}$ & $0.00 \mathrm{~B}$ \\
1.0 & $72.00 \mathrm{Aa}$ & $56.00 \mathrm{Aa}$ & $64.00 \mathrm{~A}$ \\
\hline Means & $36.00 \mathrm{a}$ & $28.00 \mathrm{a}$ \\
\hline
\end{tabular}

Means followed by same lowercase letter in rows and same uppercase letter in columns are not different from each other according to Tukey test at a $5 \%$ probability.

Sterile treatments showed no statistical differences for all analyzed variables. Explants disinfested with $70 \%$ isopropyl for 15 minutes and $8.25 \% \mathrm{NaOCl}$ for 20 minutes presented the lowest numeric value for fungal contamination (19.04\%) (Data not shown). As mentioned before, information about sterilization procedure for Miscanthus spp. is limited. For Miscanthus $\mathrm{x}$ giganteus plant material obtained from field plants, Tóth and Pepó (2006) applied $80 \%$ alcohol for the surface sterilization. In both sugarcane genotypes, sterilization with 90-95\% Ethyl alcohol (EtOH) by 10-15 minutes was efficient but toxic to explants and the best was the use of $90 \% \mathrm{EtOH}$ by 5 minutes (Tiwari; Arya; Kumar, 2012). Khan et al. (2007) studying sterilization protocols in three sugarcane cultivars observed similar behavior between cultivars and an increase of $\mathrm{NaOCl}$ concentration favored a decrease on contamination percentage and an increase in the browning. In the present work, the oxidation levels were non-significant and non-committed to survival of Miscanthus genotypes.

Regarding to differences between Isopropyl and Ehtyl alcohol, both have higher sterile function, and according to Rutala and Weber (2008), isopropyl alcohol was slightly more bactericidal than ethyl alcohol for some bacteria as Escherichia coli and Staphylococcus aureus. Ideal protocol is defined as a treatment with disinfectant solution at suitable concentrations for a specified period promoting surface sterilization without affecting biological activity of the material (Oyebanji et al., 2009).

In general, major contamination on both Miscanthus genotypes was caused by bacteria (65.72\%) against fungal (29.38\%). High contamination is probably due to a material taken from field grown plants. Other aspect to be considered is a possibility of endophytic bacteria association. These microorganisms can be isolated from visually asymptomatic, surface-sterilized plant tissues.

Bacterial communities evaluated in contaminated medium showed high diversity with 12 groups, only three (1, 2 and 6) were distributed on both accessions (Figure 1). Studies conducted by Cope-Selby et al. (2017) also showed high bacterial diversity in Miscanthus sinensis seedlings grown in a sterile environment. Magnani et al. (2010) studying the diversity of endophytic bacteria in the internal tissues of Saccharum spp. stems and leaves identified five groups.

Future studies to adjust the suitable concentration of isopropyl or ethy alcohol, sodium hypochlorite and $\mathrm{PPM}^{\mathrm{TM}}$, identification of bacterial groups, combined with strategies for control contaminants from field or greenhouse cultivation should be essential to establish an efficient micropropagation protocol for Miscanthus spp. 

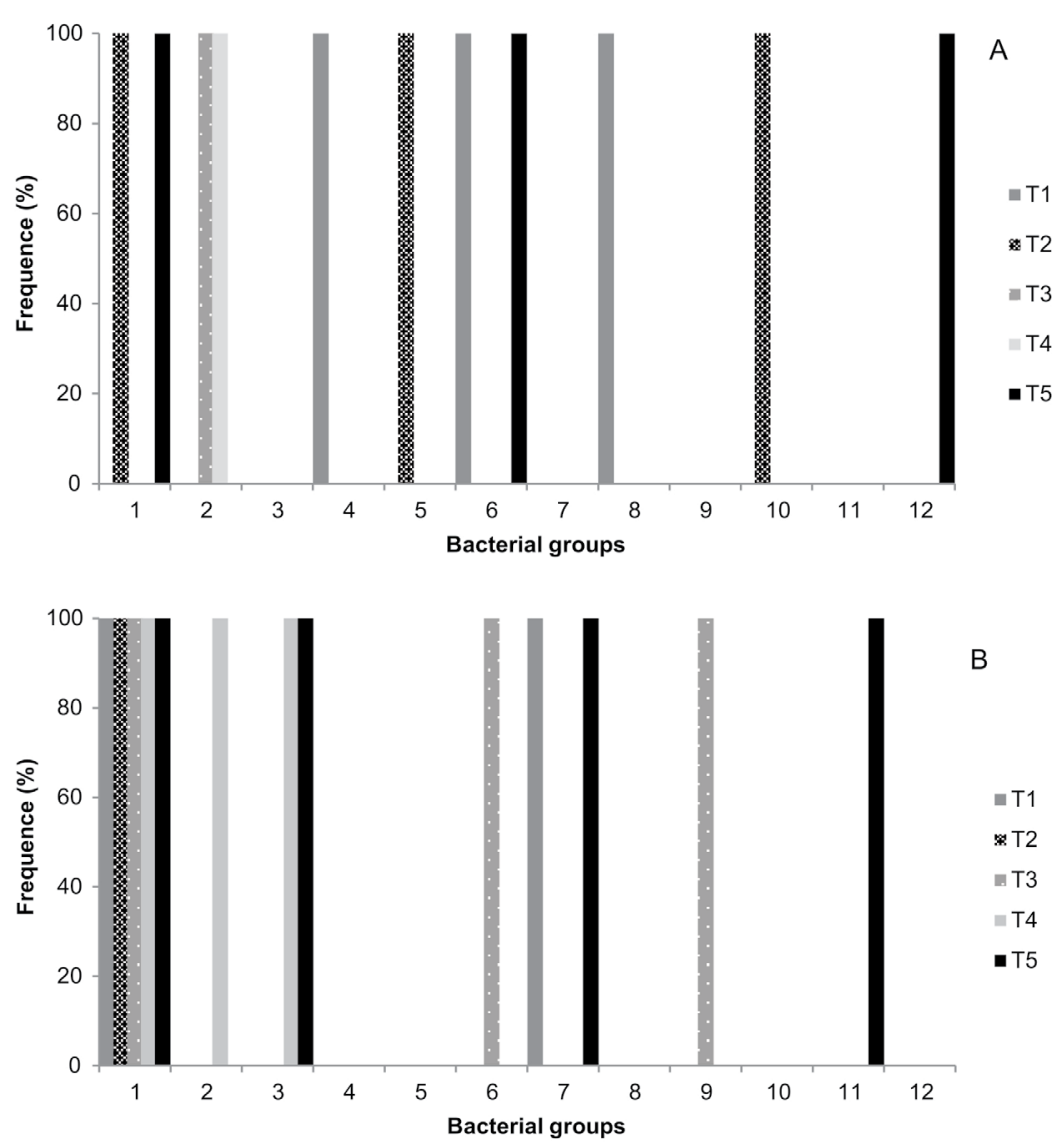

Figure 1 - Frequency distribution (\%) of 12 bacterial groups in contaminated medium samples cultivated with two Miscanthus accessions submitted on different sterilization procedures. A: PI 668371; B: PI 668375; T1- 10 min 70\% isopropyl + $20 \mathrm{~min} 1.5 \% \mathrm{NaOCl}$; T2- $15 \mathrm{~min} 70 \%$ isopropyl + $10 \mathrm{~min} 5 \% \mathrm{NaOCl}$; T3- $15 \mathrm{~min} 70 \%$ isopropyl + $20 \mathrm{~min} 5 \%$ $\mathrm{NaOCl}$; T4- $15 \mathrm{~min} 70 \%$ isopropyl $+10 \mathrm{~min} 8.25 \% \mathrm{NaOCl}$; T5- $15 \min 70 \%$ isopropyl $+20 \mathrm{~min} 8.25 \% \mathrm{NaOCl}$.

\section{CONCLUSION}

The biocid $\mathrm{PPM}^{\mathrm{TM}}$ may be an efficient agent to reduce bacterial contamination in Miscanthus sinensis apical meristems.

\section{ACKNOWLEDGMENTS}

The research was funded by Embrapa and USDAARS CRIS 3012-21000-013-00D.

\section{REFERENCES}

ATKINSON, C. J. Establishing perennial grass energy crops in the UK: A review of current propagation options for Miscanthus. Biomass and Bioenergy, 33:752-759, 2009.
BOERSMA, N. N.; HEATON, E. A. Effects of temperature, illumination and node position on stem propagation of Miscanthus $\times$ giganteus. Global Change Biology Bioenergy, 4:680-687, 2012.

CARROLL, A.; SOMERVILLE, C. Cellulosic biofuels. Annual Review of Plant Biology, 60:165-182, 2009.

CHRISTIAN, D. G.; YATES, N. E.; RICHE, A. B. Establishing Miscanthus sinensis from seed using conventional sowing methods. Industrial Crops and Products, 21:109-111, 2005.

CLIFTON-BROWN, J. C. et al. Progress in upscaling Miscanthus biomass production for the European bioeconomy with seed based hybrids. Global Change Biology Bioenergy, 9:6-17, 2017. 
COPE-SELBY, N. et al. Endophytic bacteria in Miscanthus seed: Implications for germination, vertical inheritance of endophytes, plant evolution and breeding. Global Change Biology Bioenergy, 9:57-77, 2017.

DANIELS, J.; ROACH, B. T. Taxonomy and evolution. In: HEINZ, D. J. (Org.). Sugarcane improvement through breeding. Elsiever. 1987. p.1-84.

DIGONZELLI, P.; DÍAZ, L.; CARRIZO DE BELLONE, S. Use of PPM (Plant Preservative Mixture) to control bacterial contaminants in the multiplication in vitro of sugarcane. Revista da Faculdade de Agronomía, 22:20-29, 2005.

FAIZY, H.; AL-ZUBAYDI, S.; NAIR, M. Effect of Plant Preservative Mixture $\mathrm{PPM}^{\mathrm{TM}}$ on the shoot regeneration of watercress (Nasturtium officinale). Science Journal of University of Zakho, 5(2):187-192, 2017.

JAKOB, K.; ZHOU, F.; PATERSON, A. H. Genetic improvement of C4 grasses as cellulosic biofuel feedstocks. In Vitro Cell \& Development Biology - Plant, 45:291-305, 2009.

KHAN, S. A. et al. Optimization of explant sterilization condition in sugarcane cultivars. Pakistan Journal Agricultural Research, 20:119-123, 2007. Available in: <http://agris. fao.org/agris-search/search.do?recordID=PK2009000719>. Access in: October, 10, 2018.

LANE, D. J. 16S/23S rRNA sequencing. In: STACKEBRANDT, R.; GOODFELLOW, M. (ed) Nucleic acid techniques in bacterial systematics. John Wiley \& Sons Inc. 1991. p.115-176.

MAGNANI, G. S. et al. Diversity of endophytic bacteria in Brazilian sugarcane. Genetics and Molecular Research, 9(1):250258,2010

MEKONNEN, T.; DIRO, M.; SHARMA, M. An alternative safer and cost effective surface sterilization method for sugarcane (Saccharum officinarum L.) explants. African Journal of Biotechnology, 12:6282-6286, 2013.

MIYAZAKI, J.; TAN, B. H.; ERRINGTON, S. G. Eradication of endophytic bacteria via treatment for axillary buds of Petunia hybrida using Plant Preservative Mixture (PPM ${ }^{\mathrm{TM}}$ ). Plant Cell Tissue and Organ Culture, 102:365-372, 2010.
NIEDZ, R. P. Using isothiazolone biocides to control microbial and fungal contaminants in plant tissue cultures. HortTech, 8:598-601,1998.

OYEBANJI, O. B. et al. Simple, effective and economical explant surface sterilization protocol for cowpea, rice and sorghum. Seeds African Journal Biotechnology, 8(20):5395-5399, 2009.

RIHAN, H. Z. et al. The effect of using PPM (Plant Preservative Mixture) on the development of cauliflower microshoots and the quality of artificial seed produced. Scientia Horticulturae, 141:47-52, 2012.

RUTALA, W. A.; WEBER, D. J. Guideline for disinfection and sterilization in healthcare facilities. Chapel Hill. 2008. 158p. Available in: <http://isac-net.org/PDFS/9a/9a94f2fd-44c247f4-9d4e-aac2de4eb9be.pdf>. Accesse in: October, 10, 2019.

SILVEIRA, S. S. et al. Micropropagation of Calophyllum brasiliense (Cambess.) from nodal segments. Brazilian Journal of Biology, 76(3):656-663, 2016.

STEWART, J. R. et al. The ecology and agronomy of Miscanthus sinensis, a species important to bioenergy crop development, in its native range in Japan: A review. Global Changes Biology Bioenergy, 1:126-153, 2009.

THOMAS, P.; AGRAWAL, M.; BHARATHKUMAR, C. B. Use of Plant Preservative Mixture ${ }^{\mathrm{TM}}$ for establishing in vitro cultures from field plants: Experience with papaya reveals several $\mathrm{PPM}^{\mathrm{TM}}$ tolerant endophytic bacteria. Plant Cell Reports, 36(11):1-14, 2017

TIWARI, S.; ARYA, A.; KUMAR, S. Standardizing sterilization protocol and establishment of callus culture of sugarcane for enhanced plant regeneration in vitro. Research Journal of Botany, 7:1-7, 2012.

TÓTH, S.; PEPÓ, P. Nutrient uptake of Miscanthus in vitro cultures. Journal of Natural Fibers, 3: 17-21, 2006.

WANG, X. et al. Establishment of an efficient in vitro culture and particle bombardment-mediated transformation systems in Miscanthus sinensis Anderss., a potential bioenergy crop. Bioenergy, 3(4):1-11, 2011. 